\title{
ENLIGHTENMENT AND REALISM
}

Steven Pinker, Enlightenment Now: The Case for Reason, Science, Humanism, and Progress, Allen Lane, London 2018, 162 x 38 x 240 mm, 576 pp., ISBN-10: 0241004314, ISBN-13: 978-0241004319.

\begin{abstract}
Steven Pinker's book Enlightenment Now is a landmark achievement, if it is considered only as a review of the history of social progress in the world since the mid-eighteenth century. Pinker demonstrates, beyond reasonable doubt, that great progress has been made on almost every front. But, it is argued, much of this progress has been bought at the cost of social progress in First World countries. For it has been achieved by reverse engineering the social structures to make them resemble more closely the neoclassical model of a nation's economy - a model that contains neither a government nor any socially-funded social services. The reviewer argues that the practice of changing the social facts, in order to make them fit a given theoretical model better, is contrary to scientific method, and that we need a new enlightenment now to develop scientifically more realistic theories in the social sciences.
\end{abstract}

Keywords: Enlightenment, Steven Pinker, social sciences, reverse application strategy

This book is a brilliant, spirited, and powerful defence of everything that social humanists like me really stand for. Moreover, it is all backed by solid empirical evidence. And, what is defended is what many of us have spent much of our lives trying to promote. For the progress that has undoubtedly been occurring for the last 250 years is the natural result of the now global reach of free market capitalism. And it is due also to the prevalence of the values of humanism, reason, and scientific discovery and ingenuity, which led to the European Enlightenment when the scientific world-view overtook the

* Emeritus Professor of Philosophy, La Trobe University, Bundoora (Melbourne), Victoria 3086, Australia, e-mail: brian.ellis8@bigpond.com. 
theological one. Those who would say otherwise, Pinker argues, are just being duped by the common illusions of perception that have been discovered by modern cognitive psychologists.

For these reasons, Pinker's book is a welcome contribution to the social debate. For the greatest threats to social achievement are complacency and invisibility. When social collaboration has been successful, the next generation is likely to take those successes for granted. And the successfulness of the Enlightenment project is undoubtedly one of the greatest, if not the very greatest, achievement of human kind. And we must never forget this. We must also acknowledge that this very achievement has been largely due to free trade agreements, which have enabled market capitalism to dominate trade in and between nations. By doing so, it has opened up the whole world to substantial social progress - at least on the seventeen fronts that Pinker discusses.

But, as we shall see, these achievements have their downside. For they have been bought at the expense of full employment, widespread home ownership, and social justice in the West. This was not done maliciously, I believe. For these things were all taken for granted. The problem of unemployment, it was thought, had already been solved, and well-paid employment was widely regarded as a human right. In Australia, for example, unemployment averaged just 2.0\% in the thirty years of the welfare state. Likewise, home ownership had come to be seen as a right by about 1970 . And young people thought that they could always exercise this right, if only they applied themselves to their work, and did not live recklessly. Moreover, any sacrifices that the West might make were thought, by comparison, to be trivial. The world needed to get behind a program to relieve poverty in the Third World, and to let them enjoy some of the advantages that we have long taken for granted.

Yet, for those in the First World, whose wages have been frozen at pre-1980 levels, and whose children have been denied useful employment, apparently in order that the people of the Third World may enjoy prosperity, it does not now seem to be such a good deal. These people, as we say, "have been dudded." And, why have they been dudded, we may ask? Because, at the time, almost no one thought they were at risk of losing the privileges they enjoyed.

Pinker evidently thinks that most of his opponents in the debate, which his book is almost certain to provoke, are likely to be backward-looking conservatives, who yearn for an older, and much more traditional view of human nature. For the first two, and certainly the most carefully argued, parts of the text outweigh the shorter third section, which is directed at more academic opponents, "who really care about arguments."

As one who has recently published books on scientific realism as a "first philosophy" (2009), social humanism (2012), and rationalism (2017), I think 
I can reasonably class myself as belonging to this second category. And, after reading John Lanchester's article (2018) a few weeks ago, I became more convinced than ever that the good fight for sound reasoning, science, and humanism is not yet over.

However, I also think that eighteenth century views about human nature, science, and reason are no longer acceptable (cf. Ellis 2012, 2017). They need to be replaced by some rather more enlightened ideas. So, I would not be content just to champion the Enlightenment. I think we need a new and better enlightenment.

Let us recall the history and philosophy of science, which led up to the original Enlightenment. In 1687, the young Isaac Newton published his Mathematical Principles of Natural Philosophy (hereafter, the Principia). In this book, Newton developed a finally convincing solution to the ancient problems of the shape, structure, and dynamics of the universe. His grand solution did not fit well with Aristotle's vision of the cosmos (as set out in Book 1 of De Caelo). But Newton's Principia, in which it was contained, was a powerful system of dynamics, which was developed, in Euclidean fashion, from what he believed to be self-evident truths. And, the methodology of the Principia was that of pure theory (or "rationalism," as it is nowadays known), in which he set out his "axioms of motion," and explained them, but made no attempt to justify them. Presumably, he believed these axioms were selfevident, and so not in need of justification (Ellis 1962) - just as Euclid's axioms of geometry were always thought to be.

The Principia not only created a research program for philosophers and scientists everywhere to pursue. It also convinced nearly all of the intellectual elite of Europe that the universe is rational, i.e. law-governed and a priori intelligible. In his Discourse on Method, René Descartes had argued that "all things, to the (scientific) knowledge of which mankind is capable," must, just as in geometry, be derivable by a priori reasoning. And, the Principia seemed to show that this was indeed the case. As Pope said, "Nature and Nature's laws lay hid in night. God said: Let Newton be, and all was light." Consequently, it stimulated all of the arts and sciences of the age, and fuelled the European Enlightenment. It is no exaggeration to say that it changed the way people everywhere understood the world they were living in.

Pinker, to his credit, defends the trial and error methodology of science, and regards it as one of its great strengths. If a physical theory fails to pass crucial tests, then, however attractive it may otherwise be, it cannot be the way of the world. But in the social sciences the situation is sometimes different. If a social theory, e.g. of economics, fails to pass a severe test, then there may be no need to go back to the drawing board and change the assumptions upon 
which the theory is based. For one can, in principle, simply legislate to change the structure of society in order to ensure that it more or less satisfies the axioms you have been using. This is what I call "the reverse application strategy" (Ellis 2017: Ch. 7).

Normally, if one's theory fails to predict accurately, you have no option but to revise your axioms. But, in theoretical economics, you do sometimes have a choice. If for example, your theory involves a perfect market which is attended only by perfectly rational, well-informed, and ideally self-interested beings, then you might be able to construct an economic theory that predicts convergence to a state of economic equilibrium, where there is full employment, and supply is equal to demand, provided that there is no outside (e.g. governmental) interference. But suppose that the actual system does not behave as predicted, and just when it looked as though it was coming to a state of equilibrium, it crashed, so that people lost heavily on the stock exchange, and many more lost their jobs. What to do?

The normal scientific approach would be to go back to the drawing board and develop a system that was realistic about government interference, education, social services, and so on. But there is also the reverse strategy: which is to get rid of the government or cut government interference in the economy to the barest minimum, and try again. This, roughly, is neoliberal theory. And, it makes nonsense of humanistic values, such as those of health care, unemployment relief, old age pension provisions, and education. Very few of the seventeen dimensions of progress discussed in Steven Pinker's book could possibly exist in a neoliberal society, if indeed, such a society could ever be created.

But some dreadful consequences of neoliberalism are now emerging clearly for all to see. In his Presidential Address to the American Economic Association in 2003, Nobel Prize winning macroeconomist Robert E. Lucas Jr. argued that the central problem of "Depression prevention" has been solved. Lanchester (2018) quotes him as saying:

Taking U.S. performance over the past 50 years as a benchmark, the potential for welfare gains from better long-run, supply-side policies exceeds by far the potential from further improvements in short-run demand management.

He then goes on to say:

How's that been working out? How it's been working out here in the UK is the longest period of declining real incomes in recorded economic history. 'Recorded economic history' means as far back as current techniques can reach, which is back to the end of the Napoleonic Wars. Worse than the decades that followed the Napoleonic Wars, worse than the crises that followed them, worse than the financial crises that inspired Marx, worse than the Depression, worse than both world wars. That is a truly stupen- 
dous statistic and if you knew nothing about the economy, sociology or politics of a country, and were told that single fact about it - that real incomes had been falling for the longest period ever - you would expect serious convulsions in the national life.

Later in the same paper, Lanchester adds that the US has fared no better:

... the real median hourly income in the US is [now] about the same as it was in 1971. Anyone time-travelling back to the early 1970 s would have great difficulty in explaining why the richest and most powerful country in the history of the world had four and a half decades without pandemics, country-wide disaster or world war, accompanied by unprecedented growth in corporate profits, and yet ordinary people's pay remained the same.

I am not in a position to vouch for Lanchester's observations. But if they are even roughly true, they strongly support my case for a new enlightenment. The neoliberal consensus has got to be challenged, and the reverse application strategy condemned as contrary to the trial and error methodology of science. So, I think we need a new enlightenment. Not just the old one. We need a New Enlightenment Now. We need one to correct many of the old ways of thinking about human rights and morality too. And this is precisely what I have been trying to achieve by: (a) using scientific realism as my first philosophy (Ellis 2009) to develop a scientifically realistic theory of social morality to replace Kant's rationalist one (Ellis 2012), and (b) replacing neoclassical economics with a pragmatic neo-Keynesian one (Ellis 2017) - a theory which, like all empirical scientific theories, tries to adapt its hypotheses to fit social reality. We must not, as neoliberals advocate, attempt to change social reality to make it fit the theory. Instead, we must change the theory to fit the facts, as all good scientific theories must.

\section{BIBLIOGRAPHY}

Ellis B. D. (1962), "Newton's Concept of Motive Force," Journal of the History of Ideas 23(2), 273-278.

Ellis B. D. (2009), The Metaphysics of Scientific Realism, Durham: Acumen Publishing. Ellis B. D. (2012), Social Humanism: A New Metaphysics. London-New York: Routledge. Ellis B. D. (2017), Rationalism: A Critique of Pure Theory, Melbourne: Australian Scholarly Publishing.

Lanchester J. (2018), “After the Fall,” London Review of Books 40(13), 3-8.

Pinker S. (2018), Enlightenment Now: The Case for Reason, Science, Humanism, and Progress, London: Allen Lane. 